\title{
Engineering Situational Analysis of Enterprise Economic Security
}

\author{
V.V. Lesnyak*, E.M. Selezneva \\ Department of Economic Security, Accounting and Law, Don State Technical University, Rostov-on-Don, Russia \\ "Corresponding author. Email: lesnyak2005@ rambler.ru
}

\begin{abstract}
The paper explores a new approach to engineering situational analysis of economic security of the enterprise. The proposed approach involves a varied assessment of its value for further computing a number of systemforming indicators of the initial, current and prospective level of security based on the application of engineering tools and technologies. The formation and functioning of the engineering situational analysis tools are aimed primarily at protecting property relations. The authors' innovative solution contains a structural-logical model served as the basis for arranging and conducting a situational analysis of economic security and provided multivariate and alternative protection results. Besides, the authors recommend employing situational derivative balances to assess the impact of the situational factors on enterprise economic security, to estimate the cost-effectiveness of the implemented protective measures within constant and variable blocks of the methodology. It allows creating a flexible and adaptive mechanism for managing security and developing the enterprise. The utility of the proposed methodology is highlighted by software designed to increase the efficiency and effectiveness of the settlement and analytical procedures.
\end{abstract}

Keywords: engineering tools, economic situation, situational analysis, economic security, enterprise protection mechanism, property, situational derivative balance

\section{INTRODUCTION}

The increasing dynamism of the economic environment, enormous risk rising, intensifying competition, and competitive pressure accentuate the urgent necessity to identify and analyze the threats to economic security, evaluate the effectiveness of protective measures, steps to neutralize threats and coordinate the protective functions of an enterprise. Economic globalization, interdependence, and integration of world economies, formation and development of the digital economy lead to the emergence of new threats. The given fact involves the development of adequate methodological tools targeted at determining how the effectiveness of economic security situational management correlates to the enterprise's basic indicators to ensure the owners' interests and achieve the organization's objectives.

Of particular importance in the context of the discussion presented in this paper is generating a set of engineering situational measures to regulate economic situations arising in enterprise's practical activities to ensure and manage its security and development, which determine the entire management cycle of organization protection and security management at all levels.

The analysis of economic security implies assessing the enterprise's economic interests, examining all possible threats to these interests, calculating and evaluating their compliance with economic security indicators, analyzing actual opportunities and initiatives to neutralize threats and comparing the results with the permissible (zero) hazard level in the context of a reasonable choice and use of situational protection tools.

The situational approach is constructed around the economic situation as a variable state of the enterprise's resources and sources of their formation, a combination of certain conditions and circumstances that create a specific situation in the organization: hazard risks, security level, permissible hazard level, zero hazard level, economic security zone, security margin, etc. Since the situational approach emphasizes the role of contextual factors and how they influence the enterprise, it allows calculating and interpreting a number of system-forming indicators and indices of the initial, current and prospective level of security grounded on the application of engineering tools and technologies.

Modern trends, associated with the transfer of emphasis from the property and financial results on significant events, segments and time horizons, lead to the need to use the engineering tools based on derivative balances and computer programs more actively [1].

The above-mentioned points have facilitated focusing on the choice of the topic of our research and clarifying research relevance with specific objectives to outline and solve key organizational and methodological tasks of the formation and functioning of the engineering situational analysis to examine economic security at the micro-level. Many researchers have addressed the issues of information and analytical support of enterprise economic security. In recent years there has been considerable interest in the 
problem [2-11]. In [12] the author investigated the methodological aspect of the model and the economic mechanisms of protecting a company and coordinating its protective functions, structure, and algorithms of their functioning [12]. Some experts, for instance [13], suggested recommendations on working out a unified standardization and algorithmization of the situational analysis and control processes.

Unfortunately, the formation of a situational mechanism for analyzing and managing enterprise economic security is still poorly studied. We believe the solution should be based on adequate information and analytical support with the use of engineering approaches and tools, which are an effective way to prevent environmental challenges and possible risks and threats.

The key goal of the paper is to discuss and justify methodological recommendations on arranging and carrying out the situational analysis of economic security grounded on engineering approaches, tools, and technologies. The following tasks need to be performed in connection with the above-mentioned goal: (1) to establish the structural-logical model of the situational analysis of enterprise economic security and its major structural elements; (2) to offer effective recommendations on the engineering support for the situational analysis of the security level and enterprise development based on preparation and application of the situational derivative balances.

\section{BACKGROUND}

\subsection{Structural-Logical Model of a Situational Analysis of Enterprise Economic Security}

The second half of the 20th century, especially its last quarter, became the era of large-scale globalization and informatization of the world's economic structures. Today, the rapid development of information systems and technologies, various forms of network interaction appear to support the economic activities of organizations that have reached a new level associated with network-centric business and the formation of a digital economy paradigm. Therefore, the economic protecting mechanism should be based on a comprehensive analysis of the initial level of enterprise security, its current level and the prospects for its improvement, iterative achievement of the desired protection results under the conditions of multivariate decisions and alternative results.

The analysis should proceed taking into consideration plenty of factors. Enterprise economic security is estimated based on the total cost of its property and capital, while its ability to pay is the ratio between its assets and liabilities, taking into account incoming and outgoing resources and ways of interacting with the enterprise's internal and external environment.

The situational analysis of the enterprise security level (initial, current, or prospective) is connected with assessing the level of its protection from internal and external threats, the permissible or zero danger level. The security level of an enterprise is characterized by a certain economic situation that provides effective usage and comprehensive security coverage for material, financial and information resources. Moreover, it is referred to human resource management as a gatekeeper of human potential. Thus, it is aimed at (1) ensuring the confidentiality of information, preventing insider threats and industrial espionage, restraining and combating corruption, blocking criminally dangerous economic situations and conflicts of interest caused by diverse objective and subjective factors; (2) taking into account the human factor to providing proper security level and development of the enterprise, preventing and resolving conflict situations in the workplace and restoring professional working relationships; (3) optimizing staff activities, their mental health and psychological state, supporting psychological stability in difficult, exceptional and extreme conditions, developing socio-psychological competence.

At the same time, the protective functions of the enterprise must be considered together with its adaptive capabilities, which allow making effective and timely decisions to respond to ongoing changes.

An adaptive enterprise is a business enterprise that has mastered and determinately exploits information technologies to change the enterprise culture to increase flexibility and agility of reacting to relevant changes that occur in the constantly alternating external market. Adaptive enterprises are able to develop immediate and effective solutions at the first signs of threats and opportunities in the ecosystem (i.e. market) they reside in. They implement the developed solutions straight away into the business processes of the leading office, utilizing the stable links existing in the global architecture [14].

Security serves as a basis for the protection, competitiveness, and sustainable progress of an enterprise [12] as a complex economic system that tends to develop in time and space and is integrated into the external environment.

Situational management is focused on coordinating the enterprise's protective functions in the context of separate economic situations, situational protective measures, specific protection tools, channels for implementing protective actions, and measures of neutralizing threats to manage enterprise's resources and property effectively.

Moreover, property acts as a basic indicator of the enterprise development and security level, which specifies the need to protect the owners' interests, i.e. property relations as the fundamental markers of the effective functioning of the enterprise in various situations. Property valuation is determined by the present worth of future benefits arising from the property. Considering enterprise as a property complex, property valuation procedure takes into account all its assets and the sources of their formation, assesses a wide array of external and internal factors and their possible impact, challenges, threats, and risks within the economic mechanism of the enterprise protection. Property is viewed in the context of goal- 
achieving factor support, i.e. implementation of protective measures and actions to obtain indicators of final results aggregated and disaggregated property indicators for the initial, current and prospective security level.

Indicators of enterprise economic security are a system of definite indices evaluating the effectiveness of the progress and the results of its protection based on the cost method [12], which makes it possible to apply the system of engineering indicators of property more widely. As expected, the issues of the situational analysis of enterprise economic security, the realization of protective actions and measures to neutralize threats, and the assessment of the security development management strategies relative to the enterprise value as a property complex are becoming particularly relevant and urgent.

The mechanism of protection and management goalachieving factor support, taking into account the situations of the initial, current and prospective security level, is the basis of structural-logical modeling of the situational analysis of enterprise economic security.

Considering the above-mentioned provisions from the standpoint of implementing the main provisions of the situational approach to management processes, coordination of protective functions and increasing the enterprise effectiveness, the structural-logical model should include the following elements of the situational analysis:

(1) key goal of the situational analysis: to justify management decisions, plans, and development programs; to assess the effectiveness of protective measures;

(2) objectives of the situational analysis: to single out the factors that change the initial, current and prospective security level; to calculate and establish permissible or zero hazard level; to determine all possible variants of the economic situation development; to solve the operational, tactical and strategic situational tasks;

(3) situational factors of the enterprise's internal and external environment;

(4) principles: adaptability, universality, objectivity, interpretation of the results obtained;

(5) tools of the situational analysis: a systematic presentation of calculation, analytical, control and management engineering tools in the form of derivative balances containing data on enterprise's resources and sources of their formation - databases and indicators of the initial operator, a set of iterations and the final operator (situational, strategic, semantic, structured, prognostic, alternative, scenario, adaptive, segmental, sectional, fractal, securitological, legalization and other derivative balances);

(6) indicators obtained: calculated indicators of property (absolute and relative), which serve as markers of the effectiveness of the security level and the development of the enterprise concerning its value;

(7) application of the results: substantiation of managerial decisions to ensure the competitive advantages of the enterprise to achieve strategic goals, to coordinate protective functions and provide prospects for improving the security level.
When proving the choice of objects for the situational analysis, it is necessary to cogitate about the identification criteria of emerging economic situations of the enterprise functioning, development, and security level. In addition, it is required to make accents on the following: the business entity as a whole; conditions and factors ensuring the achievement of the enterprise's strategic goals (goalachieving factor support); protective situational measures and channels to implement protective actions (measures to neutralize threats and coordinate the enterprise's protective functions); the resource efficiency and its sources (channels to use funds); competitive situations (competitive advantages).

The mechanism of the situational analysis has an internal character, whose structure includes regulatory and corrective actions, management procedures, monitoring of crisis situations and threats, coordination actions, the risk assessment process, situational prediction, and strategic foresight. Hence, the organizational model of the situational analysis is represented by the following major iterations: control of goals and objectives in the form of a set of the final result indicators; control over development plans, forecasts, options, and alternatives; analysis of the enterprise initial security level; assessment of the permissible hazard level, marginal property, and resource conditions; monitoring the implementation of protective actions and measures; iterative control and analysis of goal-achieving; monitoring and analysis of the current security level (permissible or zero hazard level); control and analysis of indicators of the resource and property effectiveness and efficiency; monitoring of the results obtained; analysis of indicators of economic security zone and margin; diagnostics and factor analysis of changes in the economic security level; assessment and analysis of prospects for improving security level; monitoring the implementation of managerial decisions and the results of solving operational, tactical and strategic tasks.

Moreover, special importance is given to monitoring the results obtained and diagnosing the enterprise security level. Various approaches have been put forward to work out these issues. Our proposal is based on the use of adaptive engineering tools.

Adaptive engineering tools represent a system of balance generalizations and interpretations of the state and condition of the enterprise resources and their sources, the methods used and means of their obtaining, summarizing and depicting the results with access to the enterprise cost indicators, formalized based on the integration of accounting, analytical and control procedures in the form of derivative balances, statements and reports that allow evaluating the effectiveness of adaptive managing the economic security processes and, if required, make appropriate adjustments: to accelerate adaptation to changing market conditions: challenges, threats, risks, and opportunities; to interactive modeling of the future and reasonable choice of means of its achievement, step-bystep approach to the desired adaptation and security results; to expand the enterprise economic growth opportunities; to conducting organizational changes [15]. 
The implementation of the situational analysis results is targeted at informed decision-making to ensure the enterprise competitive advantages in achieving strategic goals, coordinating protective functions, and providing prospects for increasing the security level.

\subsection{Engineering Support for the Situational Analysis of Enterprise Economic Security}

The presented structural-logical model determined the organizational and methodological basis for practical recommendations on effective exploiting of engineering tools for the situational analysis of enterprise economic security. These recommendations are a combination of settlement-economic, design-economic, control and audit, expert consulting, organizational and management methods carried out by control, analysis and management procedures with a focus on property indicators as a basic marker of enterprise economic security in the context of the situational approach (Table 1).

When considering issues of analyzing enterprise economic security, it is necessary to bear in mind that these issues are directly related to the demand of creating high-quality information and analytical support for management processes, monitoring threats and risks, assessing the effectiveness of protective actions and measures to neutralize threats, and evaluating the resource effectiveness. The analytical substantiation of protective measures is based on the corresponding information and analytical support, which includes analytical and diagnostic operations, diagnosis of crises, goal-achieving factor support, and monitoring the results.

The practical application of these recommendations will make it possible to interpret the results of the economic situations of ensuring and managing the enterprise security level and the prospects for its further development from the standpoint of their efficiency and increase in property value: the resource and property efficiency, actual assessment, dimensionality and analyticity of control and management, typical economic situations, engineering mechanisms, and procedures.

The engineering procedures of situational analysis are grounded on the preparation and use of situational derivative balances.

Accounting engineering management issues of enterprise economic security were considered in $[16,17,18,19]$.

The engineering methodology of accounting and analytical support of adaptive change management is based on the cardinal provisions of the evolutionary adaptive balance theory. The given theory presupposes the use of engineering tools of accounting, control, analytical, tax, network and financial nature emanated from the hypothetical implementation of assets and satisfaction of obligations in relevant prices to obtain a variety of options for enterprise balance generalizations and their sources, characterizing the level and economic character of adaptation in conditions of change [20].
The results of the situational analysis are organized as a system of engineering indicators of property - aggregated, disaggregated, structured, absolute, relative, etc. They determine the impact of situational factors and protective measures on the property state and the dynamics of the enterprise value, whose calculation is based on situational derivative balances.

The methodology of the situational analysis based on situational derivative balances includes an initial operator, a system of iterative steps (corrective, situational, specialized, and hypothetical), and corresponding results of the final operator (general change; change factors: situational deviations, factors, measures, standards, permissible levels).

The use of situational derivative balances creates a closed agility cycle. The basic steps are sensing a threat or opportunity, strategizing about options, deciding on the most appropriate action, and then communicating it before acting. This cycle must be continuous because each change must be monitored for subsequent changes [21].

The proposed methodological recommendations trace the relationship between the sequence of situational analysis stages and the general methodology of implemented control, analytical and managerial procedures.

When developing a methodology for situational analysis, it is necessary to determine the tasks to be solved by situational derivative balances taking into account the developed structural-logical model: goal and objectives, situational factors, organizational model, tools exploited, certain provisions of engineering tools for situational analysis (organizational and methodological construction, information and analytical support, technology, results)

The essence of the situational analysis methodology for enterprise economic security based on situational derivative balances lies in a certain sequence of stages that imply performing computational, analytical, control and managerial iterations:

(1) making-out a situational derivative balance in accordance with the implemented iterative algorithm before and after the realization of protective measures;

(2) assessing the main directions of the resource movement and discovering the facts of unauthorized resource movement in the context of the identified factors using the data of the general ledger, accounting records, registers, primary documents, unaccounted and reference information;

(3) evaluating the initial, current and prospective level of enterprise security;

(4) formulating conclusions on the results obtained and preparing recommendations on making appropriate decisions on alteration of the enterprise's protective mechanism.

The proposed engineering techniques, methods, and procedures are implemented in a certain sequence and determine the technology of the situational analysis.

Thus, the presented provisions specified the engineering focus of the methodology based on making-out and employing a situational derivative balance to improve the enterprise's protective mechanism (Table 2). 
Table 1 Recommendations on engineering support for the situational analysis of enterprise economic security

\begin{tabular}{|c|c|c|}
\hline Objectives & $\begin{array}{l}\text { Structural elements of the } \\
\text { situational analysis system }\end{array}$ & $\begin{array}{l}\text { Correlation with the processes of ensuring and } \\
\text { managing enterprise economic security }\end{array}$ \\
\hline \multicolumn{3}{|c|}{ Settlement-economic and design-economic methods } \\
\hline $\begin{array}{l}\text { Data collection, processing, and } \\
\text { presentation }\end{array}$ & $\begin{array}{l}\text { Initial level of enterprise } \\
\text { security }\end{array}$ & $\begin{array}{l}\text { Information support for management decisions, taking } \\
\text { into account factors of the enterprise's internal and } \\
\text { external environment }\end{array}$ \\
\hline $\begin{array}{l}\text { Justification of the choice of methods } \\
\text { for calculating economic indicators }\end{array}$ & Goal-achieving factor support & $\begin{array}{l}\text { Assessment of economic situations concerning the cost } \\
\text { of the enterprise - a basic indicator of its economic } \\
\text { security }\end{array}$ \\
\hline $\begin{array}{l}\text { Calculation of economic indicators, } \\
\text { characterizing the activities of the } \\
\text { enterprise }\end{array}$ & $\begin{array}{l}\text { Indicators of efficiency and } \\
\text { effectiveness }\end{array}$ & $\begin{array}{l}\text { Calculation, analysis, and evaluation of current and } \\
\text { forecast economic situation }\end{array}$ \\
\hline $\begin{array}{l}\text { Working-out of planned income and } \\
\text { expense indicators, comparison with } \\
\text { actually obtained ones }\end{array}$ & $\begin{array}{l}\text { System of goals, expressed by a } \\
\text { set of final indicators }\end{array}$ & $\begin{array}{l}\text { Application of a situational approach to business } \\
\text { planning and budgeting; development of budgets } \\
\text { according to the functional principle with an } \\
\text { orientation to typical economic situations; analysis of } \\
\text { calculated indicators, monitoring the plan } \\
\text { implementations, analysis of deviations obtained }\end{array}$ \\
\hline Summary and presentation of a report & Diagnostics & $\begin{array}{l}\text { Situational record, control, and analysis in the system } \\
\text { of ensuring and managing enterprise economic security }\end{array}$ \\
\hline \multicolumn{3}{|c|}{ Control and audit methods } \\
\hline $\begin{array}{l}\text { Control measures to identify and } \\
\text { eliminate violations }\end{array}$ & $\begin{array}{l}\text { Methods to implement protective } \\
\text { measures }\end{array}$ & $\begin{array}{l}\text { Arrangement and conduct of situational control; } \\
\text { solution of operational, tactical and strategic situational } \\
\text { tasks; assessment and analysis of deviations from the } \\
\text { standard values }\end{array}$ \\
\hline $\begin{array}{l}\text { Control over enterprise financial and } \\
\text { economic activities }\end{array}$ & $\begin{array}{l}\text { Monitoring the results obtained } \\
\text { Resource input } \\
\text { Resource output }\end{array}$ & $\begin{array}{l}\text { Establishment of the resource and property } \\
\text { effectiveness while implementing protective measures } \\
\text { and actions, measures to neutralize threats and } \\
\text { coordinating the enterprise's protective functions }\end{array}$ \\
\hline $\begin{array}{l}\text { Analysis of indicators of the enterprise } \\
\text { economic activities }\end{array}$ & Analysis & $\begin{array}{l}\text { Calculation and assessment of engineering indicators } \\
\text { of property }\end{array}$ \\
\hline $\begin{array}{l}\text { Analysis of control results, study, and } \\
\text { generalization of the deviation causes } \\
\text { and consequences; preparation of } \\
\text { proposals to eliminate them }\end{array}$ & Corrective measures & $\begin{array}{l}\text { The effectiveness of solving the given problem is seen } \\
\text { during controlling the planned indicators, identifying } \\
\text { deviations, and implementing corrective actions to } \\
\text { coordinate the enterprise's protective function }\end{array}$ \\
\hline \multicolumn{3}{|c|}{ Expert consulting methods } \\
\hline Economic expertise and expert studies & Goal-achieving factor support & Expert assessment of unlawful economic situations \\
\hline $\begin{array}{l}\text { Application of various methods of } \\
\text { economic expert studies }\end{array}$ & Analysis and diagnostics & $\begin{array}{l}\text { Methods of expert assessing civil, accounting and tax } \\
\text { consequences of criminally dangerous economic } \\
\text { situations; evaluation of the enterprise potential in } \\
\text { making risk decisions based on the calculation of } \\
\text { absolute and relative engineering indicators }\end{array}$ \\
\hline $\begin{array}{l}\text { Economic expertise of regulatory legal } \\
\text { acts }\end{array}$ & Goal-achieving factor support & $\begin{array}{l}\text { Detection of potential threats to enterprise economic } \\
\text { security }\end{array}$ \\
\hline \multicolumn{3}{|c|}{ Organizational and management methods } \\
\hline $\begin{array}{l}\text { Consideration of human factor in the } \\
\text { system of measures to ensure enterprise } \\
\text { economic security }\end{array}$ & $\begin{array}{l}\text { Channels to implement } \\
\text { protective actions }\end{array}$ & $\begin{array}{l}\text { Situations of proving human resource security and } \\
\text { managing human resources, assessment of threats to } \\
\text { human resource security }\end{array}$ \\
\hline Risk management and analysis & $\begin{array}{l}\text { Analysis of goal-achieving } \\
\text { factor support }\end{array}$ & $\begin{array}{l}\text { Analysis of risk situations; usage of engineering } \\
\text { methods and tools for measuring utility in the case of } \\
\text { the choice of diverse solutions; modeling of rational } \\
\text { decision making subject to agreement on the utility } \\
\text { values related to each choice }\end{array}$ \\
\hline Making optimal managerial decisions & $\begin{array}{l}\text { Methods of implementing } \\
\text { protective measures } \\
\text { Alteration of the mechanism }\end{array}$ & $\begin{array}{l}\text { Selection, development, and implementation of an } \\
\text { option for the enterprise secure development, its } \\
\text { alteration, and assessment of the effectiveness in the } \\
\text { context of conducted actions }\end{array}$ \\
\hline
\end{tabular}


Table 2 Engineering focus of the methodology for conducting a situational analysis of enterprise economic security

\begin{tabular}{|l|l|l|}
\hline \multicolumn{1}{|c|}{ Objectives } & $\begin{array}{l}\text { Structural elements of } \\
\text { the situational analysis } \\
\text { system }\end{array}$ & $\begin{array}{c}\text { Correlation with the processes of ensuring and } \\
\text { managing enterprise economic security }\end{array}$ \\
\hline $\begin{array}{l}\text { Engineering support for procedures of the } \\
\text { situation analysis of enterprise economic } \\
\text { security }\end{array}$ & $\begin{array}{l}\text { Specific protection } \\
\text { tools }\end{array}$ & $\begin{array}{l}\text { Formation and functioning of engineering tools of a } \\
\text { situational derivative balance }\end{array}$ \\
\hline $\begin{array}{l}\text { Examination of the conditions of the } \\
\text { enterprise functioning; calculation and } \\
\text { analytical justification of measures to provide } \\
\text { security, methods, and analysis tools }\end{array}$ & $\begin{array}{l}\text { Assessment of the } \\
\text { current level and } \\
\text { prospects for } \\
\text { improving security }\end{array}$ & $\begin{array}{l}\text { Directions, technologies, mechanisms, and algorithms for } \\
\text { calculating zone and margin indicators of the economic } \\
\text { security, development and implementation on their basis } \\
\text { the protective measures, channels for protective actions, } \\
\text { and corrective measures }\end{array}$ \\
\hline $\begin{array}{l}\text { Assessment of the results obtained, their } \\
\text { interpretation, and generalization, formulation } \\
\text { of conclusions }\end{array}$ & $\begin{array}{l}\text { Alterations of the } \\
\text { enterprise's protective } \\
\text { mechanism }\end{array}$ & $\begin{array}{l}\text { Information and analytical justification of assessing the } \\
\text { impact of situational factors and measures on enterprise } \\
\text { economic security }\end{array}$ \\
\hline $\begin{array}{l}\text { Development of the situational analysis } \\
\text { technology }\end{array}$ & $\begin{array}{l}\text { Initial, current and } \\
\text { prospective level of } \\
\text { enterprise security }\end{array}$ & $\begin{array}{l}\text { Application of the data system of the initial operator, a } \\
\text { complex of settlement-analytical, control and managerial } \\
\text { iterations, the final operator in the system of a situational } \\
\text { derivative balance }\end{array}$ \\
\hline
\end{tabular}

The methodology of the situational analysis of enterprise economic security has a block structure containing constant and variable blocks. The constant block includes two sub-blocks: (1) a situational derivative balance; (2) analysis of the zone and margin of economic security. The recommendations on assessing the impact of the situational factors and measures on enterprise economic security serve as a variable block. The practical implementation of the methodological recommendations is provided by the approbation of the constant block in the form of two technologies of the variable one.

Due to its block structure, the proposed method is characterized with sufficient flexibility and adaptability, which allow removing or inserting additional blocks into a variable one if necessary, taking into account the directions, goals, and objectives of the situational analysis, types of the procedures employed, protective measures, and engineering tools.

The use of engineering tools for situational derivative balances is ensured by analysis problems solved by derivative balances and the corresponding iterative algorithm. Preparation of situational derivative balances is aimed at controlling changes in enterprise economic security through its value indicators, comparing the dynamics of net assets and net liabilities in the context of protective measures and actions, formulating conclusions to make informed managerial decisions.

Making-out and further usage of derivative balances make it possible to obtain engineering zone and margin indicators of economic security based on calculated aggregated and disaggregated property indicators. The comparison of the obtained indicators of net assets and net liabilities helps to set the economic security zone as an indicator of the protective measure effectiveness in terms of the aggregated state of the enterprise's resources and their sources; while the economic security margin indicator is calculated by contrasting the obtained values of net assets and net liabilities to the established standard value of resources [22].
The results are presented in the form of a situational report containing conclusions and recommendations to the owners, CEO, and managerial staff of the organization. It describes the economic security level and prospects for its improvement, the necessity to carry out corrective actions: to reduce hazards and threats to a permissible level; to eliminate existing and potential threats; to prevent damage; to take existing and potential opportunities and initiatives, to find a new direction of economic growth or to shift economic activity towards more profitable industries [23]. These recommendations suggest structuring the economic situation of the enterprise property dynamics, reflecting the possible alterations in its economic security level, to assess the situation objectively and make the necessary decisions aimed at ensuring the enterprise secure functioning and protection, implementing the positive effects of protection, and increasing the long-term efficiency of the enterprise activities.

\section{RESULTS}

The development and wide application of engineering analysis tools are exceptionally urgent in the dynamic changes of the enterprise's external environment, the emergence of new challenges and threats to enterprise security, the growing complexity of risks, and increased competition. Therefore, it is proposed to use the corresponding software to carry out a situational analysis of enterprise economic security.

The software and hardware implementation of the engineering situational analysis of economic security, considering its information base, is presented in the form of a system: (1) initial operators as a set of aggregates and indicators (structured charts of accounts, accounting data, balance sheets, reference data); (2) algorithms of settlement-analytical, control and management procedures; (3) final operator which claims to be the results of derivative balances depicting enterprise's resources and 
sources of their formation: situational, structured, adaptive, securitological, legalization, forecast and other balances. The evidence from this study allowed us to develop a number of software products (computer programs) to conduct an engineering situational analysis of enterprise economic security. Of major interest is the following software, which has a practical application and can be an alternative to the already existing one:

(1) Implementation of adaptive and securitological derivative balance generalizations in the economic mechanism for protecting the enterprise (Patent No. 2018618438).

It is designed to obtain relevant information in the form of derivative balance generalizations to assess the effectiveness of adaptive-protective measures and actions. It allows defining indicators of the enterprise security level (initial, current or prospective security level) in the connection to enterprise economic and property relations. Besides, it analyzes the cause-effect relationships between challenges and threats to economic security, forms, methods and tools to prevent against them within the framework of an integrated economic mechanism for enterprise protection with access to aggregated and disaggregated indicators of its real value, which determine the effectiveness and efficiency of this mechanism. For these purposes, it is advised to exploit engineering tools in the form of adaptive and securitological derivative balance generalizations, which assist in determining the zone and margin of economic security taking into account incoming and outgoing resources from the standpoint of their aggregated state.

(2) Adaptive engineering tools for ensuring enterprise economic security (legalization derivative balance) (Patent No. 2018618856).

The given software is intended to reflect and assess the consequences of unlawful actions by interested parties in accounting and algorithmization of settlement-control and analytical procedures. It makes possible to determine the area of change in the enterprise value to ensure economic security grounded on adaptive engineering tools of legalization derivative balance. The program uses formulas and algorithms for generating posting amounts in legalization and hypothetical records in the corresponding accounting cycle with access to property indicators to evaluate and control the results of the forensic and price components of the property dynamics. Moreover, this software can be applied to arrange and conduct economic and forensic analysis.

(3) Implementation of accounting and analytical engineering tools for integrated management of adaptive protection processes in the enterprise (Patent No. 2019610786).

The program is designed to describe the adaptive capabilities of the enterprise integrated accounting and analytical system in accounting and algorithmization of settlement, analytical and control procedures based on engineering tools. It helps to single out the changes in the enterprise value during the implementation of adaptive and protective processes to form an information field to manage these processes. The program uses formulas and algorithms for generating posting amounts for hypothetical, adaptive and protective records to evaluate the results of changes in the enterprise value.

The goals and directions of using resources, when putting diverse protective actions and measures into practice to ensure enterprise economic security, determine the variability of the property indicators state and their dynamics as a major indicator of management efficiency [23]. Our observations suggest applying the above-listed software within the framework of the enterprise's protection mechanism: initial security level; goals expressed by indicators of the obtained (desired) results; goal-achieving factor support; methods for implementing protective measures and the protective tools employed; current security level of the enterprise; monitoring of the results obtained; prospects for further improving the security level.

\section{CONCLUSION}

Our research has provided a powerful tool for arranging and carrying out a situational analysis of enterprise economic security at the micro-level using engineering approaches, tools, and technologies. We have succeeded in creating the structural-logical model of the situational analysis of enterprise economic security, highlighting its structural elements and key characteristics. The recommendations on the engineering support for situational analysis to ensure the security level and the development of the enterprise based on the engineering tools of a situational derivative balance seem to be very promising and could be put into practice in any enterprise.

We have confirmed that structural-logical modeling of the situational analysis of enterprise economic security determines the validity of the choice and systematic nature of the management objects (the enterprise as a whole, separate economic situations) considering the presented elements that serve as a ground for the organization and analysis. Besides, it maintains multivariant and alternative results of the enterprise protection and security level - the initial, current, and prospective.

Furthermore, we have devised a methodology, which aids in conducting the situational analysis by making-out and employing situational derivative balances. It allows assessing the impact of situational factors on enterprise economic security, evaluating the effectiveness of the situational measures within the framework of the general analysis technology, taking into account the block structure (constant block, variable block). It has a clear advantage since it allows deleting and inserting additional blocks as necessary, taking into account the directions, goals, objectives, and tools used to realize the enterprise's protective functions. This methodology and the recommendations are aimed at creating a flexible adaptive mechanism for managing the enterprise development and security level based on adequate information and analytical support exploiting engineering tools and mechanisms. 
The significance of our work lies in solving the problems of arranging and conducting the analysis of enterprise security based on engineering tools within the framework of a systemic economic mechanism. In our view, it will contribute to increasing the efficiency and effectiveness of the settlement, analytical and managerial procedures. In addition, it will promote the analytical validity of managerial decisions targeted at protecting life important components of the enterprise structure and economic activities.

\section{REFERENCES}

[1] A.I. Belousov, G.V. Mikhailova, F.M. Uzdenova, V.G. Blokhina, Accounting engineering tools in the research of economic costs and benefits, in: European research studies journal, vol. 20, issue 3b, 2017, pp. 13-21. DOI: https://doi.org/10.35808/ersj/761

[2] S. Rahim, Place of accounting in providing economic safety to the enterprises (company), in: Journal of accounting and marketing, vol. 5, issue 3, 2016, pp. 1-2. DOI: https://doi.org/10.4172/2168-9601.1000185

[3] K. Raczkowski, F. Schneider, The economic security of business transactions: management in business, Chartridge Books Oxford, 2013.

[4] M. Kahler, Economic security in an era of globalization: definition and provision, in: The Pacific Review, vol. 17 (4), January, 2004, pp. 485-502. DOI: https://doi.org/10.1080/0951274042000326032

[5] T. Zubko, The Diagnosis of economic security of the enterprise, in: Herald of Knute, vol. 6, 2019, pp. 85-92. DOI: https://doi.org/10.31617/visnik.knute.2019(128)08

[6] S.V. Bank, V.D. Sekerin, A.E. Gorokhova, N.I. Nikolaykin, A.G. Shcherbakov, Risks and threats posed to a company's economic security, in: International journal of engineering and technology, vol. 7 (3.15), 2018, pp. 210-215. DOI: https://doi.org/10.14419/ijet.v7i3.15.18673

[7] Economic security for a better world, Geneva, International labour office, 2004.

[8] N. Avanesova, Y. Chuprin, Enterprise economic security: essential characteristics of the concept, in: Innovative technologies and scientific solutions for industries, vol. 1 (1), 2017, pp. 98-102. DOI: https://doi.org/10.30837/25229818.2017.1.098

[9] G. Blakyta, T. Ganushchak, Enterprise financial security as a component of the economic security of the state, in: Investment management and financial innovations, vol. 15, issue 2, 2018, pp. 248-256. DOI:

https://dx.doi.org/10.21511/imfi.15(2).2018.22

[10] L. Domracheva, E. Karanina, A. Bakhtimov, M. Kochetkov, Audit of economic security as an effective tool to prevent corruption in a construction company, in: MATEC Web of Conferences 193, 05067 (2018), ESCI, 2018, pp. 1-8. DOI: https://doi.org/10.1051/matecconf/201819305067
[11] S. Drobyazko, Personnel management as an element of the company economic security system, in: Rocznik administracji publicznej, vol. 4, 2018, pp. 210-218. DOI: https://doi.org/10.4467/24497800rap.18.012.9227

[12] M.I. Korolev, The economic security of a firm: theory, practice, choice of strategy, Moscow, Economica publ., 2011.

[13] I.V. Lesnyak, Situational analysis and control in the commercial enterprises, Rostov-on-Don, Rostov state university of civil engineering, 2009.

[14] T. Elliott, D. Herbert, Joined Up Systems: Building the Integrated Business, Hodder Headline, 2002.

[15] G.E. Krokhicheva, V.V. Lesnyak, E.M. Selezneva, E.S. Arakelyants, Adaptive engineering management tools of enterprise economic security, in: Management Science Letters, vol. 8, issue 6, 2018, pp. 605-618. DOI: https://doi.org/10.5267/j.msl.2018.4.030

[16] V.V. Lesnyak, Accounting engineering management of the enterprise economic security, Rostov-on-Don, Don State Technical University, 2019.

[17] O.V. Godina, L.S. Maksimenko, Y.Y. Kosenkova, Y.R. Mezentseva, T.A. Shcherbakova, Strategic directions of innovational development of socio-economic systems, in: Advances in intelligent systems and computing, issue 726, 2019, pp. 118-127. DOI: https://doi.org/10.1007/978-3-31990835-9_14

[18] N.A. Myasnikova, A.V. Sidashov, Ph.V. Myasnikov, The formation and functioning of surface nanostructures at tribocontact, in: Materials Science Forum, vol. 870, 2016, pp. 303-308. DOI:

https://doi.org/10.4028/www.scientific.net/MSF.870.303

[19] Sidashov A.V., I.V. Kolesnikov, Nonequilibrium processes of segregation and diffusion in metal-polymer tribosystems, in: AIP Conference Proceedings International Conference on Mechanics, Resource and Diagnostics of Materials and Structures, MRDMS 2017, vol. 1915, 2017. DOI: https://doi.org/10.1063/1.5017319

[20] V.V. Lesnyak, Adaptive architecture of the enterprise accounting and analytical system, in: Smart Technologies and Innovations in Design for Control of Technological Processes and Objects: Economy and Production. Proceeding of the International Science and Technology Conference «FarEastCon-2018», vol. 1, Springer, Cham, 2020, pp. 297306. DOI: https://doi.org/10.1007/978-3-030-15577-3_29

[21] J. Taylor, N. Raden, Smart Enough Systems: How to Deliver Competitive Advantage by Automating Hidden Decisions, Pearson Education Inc., Prentice Hall, 2007.

[22] V.V. Lesnyak, Model of formation and functioning of adaptive engineering tools, in: PNRPU Sociology and Economics Bulletin, vol. 2, 2018, pp. 223-232. DOI: https://doi.org/10.15593/2224-9354/2018.2.22

[23] V.V. Lesnyak, G.E. Krokhicheva, E.M. Selezneva, Accounting adaptive engineering tools and its use in the management of adaptive-protective processes, in: KANT, vol. 1 (30), 2019, pp. 292-299. DOI: https://doi.org/10.24923/2222-243X-2019-30-1 